\title{
A new general dictionary of Ume Saami
}

BArruk, Henrik. 2018. Báhkuogirjjie: Ubmejesámien-dáruon, Dáruon-ubmejesámien $=$ Ordbok:Umesamisk-svensk, Svenskumesamisk. Umeå. 301 pp.

Among the Western Saami languages, Ume Saami has the least written representation and the lowest number of speakers (currently a few dozen at most; see e.g. Sámediggi 2018). One of the obstacles to revitalisation work has been the lack of an easy-to-use dictionary: up until now, the most recent dictionary of Ume Saami was Wolfgang Schlachter's dictionary of the Malå dialect of the language, published in 1958, which has long been sold out and which, as a scientific dialect dictionary, uses German as its metalanguage. With this in mind, the publication of a new Ume SaamiSwedish-Ume Saami dictionary is happy and long-awaited news.

The new dictionary is the result of long-term gathering work by Henrik Barruk: in his preamble, he says that he started to write down the words of his parents when he was a child. The work became more goal-oriented in nature at the start of the 20oos, when a working group of five Saami elders came to Barruk's aid and began listing words based on their oral histories. In addition to the working group's language skills and observations on the contemporary language, Barruk has utilised Schlachter's dictionary, dialect notes by Axel Calleberg, Nils Moosberg and Jonas Nensén stored in the Swedish archives, and, to some extent, old Swedish Saami Bible translations and Lindahl and Öhrling's dictionary from 1780 , which are mentioned in the references of the work. First and foremost, the dictionary is intended for everyday use - to provide a foundation for studies and the development of language skills, as Barruk states in the preamble - but linguists, who have had to rely thus far on Schlachter's dictionary, essentially based on the idiolect of one speaker of a single dialect, could also hope that the new dictionary would provide a somewhat broader lexicological resource. In the following, I will assess the usefulness of the dictionary first and foremost from the perspective of a researcher. Olle Kejonen (2019) has recently written a more general assessment of the book.

The appearance of the book is deserving of praise, but also a small reproach. The layout and cover design are elegant in their simplicity and pleasant to read, and map of the speaking area of Ume Saami on 
the inner cover is a nice addition. The hard covers are undoubtedly good from the perspective of durability. However, the usability of the book is hampered by the stiff adhesive on the spine, which means that the book does not stay open except under the weight of a hand or at least half a kilogram. The use of an adhesive binding technique also poses a risk of pages coming loose with intensive use over time.

In presenting Saami words, Barruk's dictionary uses a newly established spelling (Arbetsgrupp 2016) that resembles the orthography of Lule and Pite Saami and is more user friendly than the subphonemic marking used by Schlachter. A noteworthy shortcoming in the orthography is that it does not distinguish between long (open) and short (close) $o$-vowels, using $a$ to mark both (cf. e.g. dågga /o/ 'in that direction' and dagga /ō/ 'in this direction'). ${ }^{1}$ The relationship between writing and pronunciation is explained to a satisfactory degree in the introduction to the dictionary, although the somewhat disjointed vowel alternation table provided here would probably need a clearer layout and explanations to be understood by someone not familiar with Ume Saami phonology. When it comes to the letter $\ddot{u}$ (the central vowel $/ \mathrm{u} /$ ), the alphabetisation is inconsistent: in the grapheme list in the introduction, it is presented between $u$ and $v$, whereas in the word entries, it appears after $y$ (the front vowel / $\mathrm{u} /$ ) as an initial. Wordinternally, though, it is alphabetised together with $y$.

The word entries in the book are concise and informative; in addition to translations, the word class is provided for each word and, if necessary, the oblique stem and any phonetic variants, which also have their own reference entries. For some words, examples of usage are also provided. The phonetic variants are usually regular variants from different dialects; the forms belonging to the Malå and Arvidsjaur dialects are marked with an asterisk (e.g. geärggie ${ }^{*}$ geäđggie 'rock'). Lexicologists would benefit from more detailed dialect and

1. When deciding on the orthography, there would have been an excellent opportunity to distinguish the short $o$ from the long one using the grapheme 〈o〉, which is now used only in the latter component of the diphthong <uo〉. Here, the orthographic model of the Scandinavian languages and Lule, Pite and South Saami seems to have taken precedence over the principle of indicating phonemic differences. That said, the grapheme « $u$ 〉, for example, is used to indicate the vowel $u$, despite its differing phonetic value [u] in Swedish, Norwegian and South Saami. 
source information, but understandably there is no place for it in a general dictionary of this kind.

That said, researchers of historical-comparative lexicology are aided by the fact that the original $d$ is presented as its own phoneme (with the dialectal variants $d \sim r$ ), whereas in Schlachter's dictionary, this sound cannot be distinguished from d. Generally speaking, Barruk's dictionary uses a more systematic historical phonemicisation in cases where the realisations of two phonemes overlap; as a comparison, Schlachter sometimes marks the etymologically long á as $a$, (e.g. vasstèdit vs. Barruk: vásstiedit 'answer' $\neq$ vasstie 'ugly'). This likely reflects the handiwork of Professor Emeritus Olavi Korhonen, who is commended in the preamble to the dictionary for his great help during the editorial work.

The new dictionary is stated to have a scope of more than 5,000 Saami entries, whereas Schlachter's dictionary has just under 6,000 words. How has Barruk, using sources that are in principle much more extensive than Schlachter's, managed to produce a dictionary of around the same scope? Looking at the two dictionaries side by side, it appears that the material has been limited by excluding a large number of derivations and vocabulary that the editor apparently did not consider important for contemporary users. In the following, I will illustrate the differences between the two dictionaries by comparing the Ume Saami words they contain beginning with $v$. For the comparison, I have used an electronic version of Schlachter's dictionary data, where I have sought to programmatically convert the headwords into the spelling and alphabetisation used by Barruk. $^{2}$

Barruk's dictionary contains a total of 318 entries beginning with the letter $v$ when entries indicating regular dialectal variants (vuadđuo $\rightarrow$ vuarruo) and variants in inflectional class (viärrage $\rightarrow$ viära : viärrag-) are subtracted from the total. The total number of comparable words beginning with $v$ in Schlachter's dictionary is 453 . Excluding minor differences in phonetic form and meaning, there are 200 words that can be identified as common to both dictionaries,

2. The material is based on the Ume Saami vocabulary provided in the Álgu database (http://kaino.kotus.fi/algu/), which contains Schlachter's dictionary in its entirety (with minor additions). The data converted into the modern orthography and the program used for the conversion are available at https://doi.org/10.5281/zenodo.4163676, and a comparison table of the $v$-words can be found at https://doi.org/10.5281/zenodo.4166780. 
including (B) viärrat (S) feärrat 'carve', which is found under $f$ in Schlachter. In addition, some basic words that are surprisingly missing from Barruk's entries can in fact be found in the Swedish-Ume Saami section of the same dictionary: these include at least váhrá váhđá 'danger' (s.v. fara), varries 'fresh' (s.v. frisk), viäralde 'world' (s.v. värld), vuajgyat vuajyatit 'breathe' (s.v. andas), vuassa 'sack' (s.v. säck) and vuösstie- 'counter-, against (in compounds)' (s.v. mot-). In other words, the two directions of the dictionary do not fully correspond to one another in terms of their content.

Based on the above, as many as 246 of the words beginning with $v$ in Schlachter's dictionary, i.e. more than half, are not found in Barruk's. Most of the words omitted are compound words or derivations, particularly aspectual verbs and adjectives. For example, for the following series of derivations, Barruk's dictionary provides only the stem verbs (in boldface):

$\begin{array}{ll}\begin{array}{ll}\text { vadnat } \\ \text { 'stretch (intr.)' }\end{array} & \begin{array}{l}\text { viässuot } \\ \text { 'live' }\end{array} \\ \text { vadnatit } & \begin{array}{l}\text { vyössat } \\ \text { 'stretch (tr.)' }\end{array} \\ \begin{array}{l}\text { 'receive life (e.g. } \\ \text { of a newborn)' }\end{array} \\ \begin{array}{l}\text { vadnatallat } \\ \text { 'stretch oneself' }\end{array} & \begin{array}{l}\text { vyössijit } \\ \text { 'recover' } \\ \text { vyössijahttiet } \\ \text { 'bring back } \\ \text { to life' }\end{array}\end{array}$

In addition, certain (near-)synonymous derivations have been omitted. Along with the word varrasmuvvat 'heal, recover', for example, Schlachter provides the near-synonymous derivations varrasmit, varrasmáhtjat, and varrastuvvat, which Barruk does not include. Regular inchoative derivations in -gåhtiet have been included by providing only the suffix as an entry. Adjectives in -ladtje are included selectively (vïssjuoladtje 'enemy', but not, for instance, veälggáladtje 'debtor'), as are abstract nouns in -vuahta (viänagisvuahta 'friendship', but not, for instance, vïsjaladtjevuahta 'hostility'). Caritive adjectives such as viehkiet(iebmie) 'helpless' and vuajat(iebmie) 'fat-free' seem to have been omitted altogether.

It makes sense to exclude transparent derivations of this sort from a dictionary with a limited scope, as the meaning can usually be inferred from the parts of the word. When it comes to productive derivation types, listing all possible derivations would also take up an unreasonable amount of space. The starting point is thus quite different from that of an exhaustive dialect dictionary, which is important to bear in mind when using this dictionary for research purposes.

Words have also been included or omitted on non-morphological 
grounds. Although the introduction to the dictionary states that the majority of the vocabulary is related to the traditional sphere of life of the Ume Saami people, some vocabulary connected to former livelihoods and beliefs has also been omitted (cf. Schlachter's várbbie 'seine fishing spot', virbmas 'skilled at recognising earmarks', vänttje 'ghost'). Some of the words found in Schlachter's dictionary have probably been considered too marginal in the Ume Saami language area; for example, the phonetic form of the word vuövddiet 'sell' suggests that it has been borrowed from a more northern Saami variety (cf. the regular form vuöbddiet 'id.' $\left.{ }^{*}{ }^{*} v u o m t \bar{e}-\right)$. On the other hand, the South Saami-type variant vïnttsa 'boat' of the word vadnas 'id.' has been included.

The new dictionary contains $118 v$-words that are not included in Schlachter's dictionary. In terms of their semantics, many of these appear to be fairly basic vocabulary items that Schlachter simply did not come across when collecting his materials, such as vaháge 'damage', várjjuo 'weapon', vïdnjuo 'sloping, askew', vuastuo 'uphill', and veäjkkat 'dive'. The additions also include some adverbs and relational words, such as vïhttás(i)t 'surely, probably', vuan vuon 'surely; of course; otherwise' and villabe 'regarding (related to the following sentence)'. The new dictionary also includes some common derivations and compounds not found in Schlachter's, such as the compounds veälljabiellie 'halfbrother', vuapttatjållie 'strand of hair', vulasvuarruo 'autumn migration', the nominal derivations vádtsátahkka 'path', välljeme 'choice', vuöhtijije 'shooter', and the verbal derivations viähkasjit 'give help', vïjssuot 'become wise(r)', $\operatorname{valgg}(a)$ sit 'start walking' and vuajdnasaddat 'see one another'.

As a general impression, compared to Schlachter's dictionary, Barruk's is more comprehensive when it comes to the basic vocabulary commonly used in the language, which is the main purpose of a general dictionary. In some respects, the scope seems somewhat random, which is probably largely due to the fact that Barruk's dictionary is also based on field and archive materials and not, for example, on a pre-edited dictionary template. There are also peculiar gaps in certain semantic fields; for example, the kinship terms vijvva 'son-in-law' and vuöniev 'mother-in-law' are included, but vuahpa 'father-in-law' (found in Schlachter) is not. The following superlative adjectives in -mus are included in both Schlachter's and Barruk's dictionaries: 


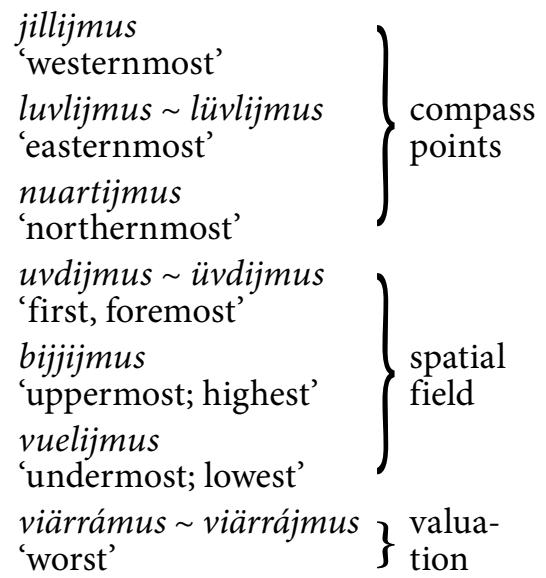

In Barruk's dictionary, the list also includes the spatial terms jillijmus 'highest' and minnijmus 'last, hindmost'. What is strange, on the other hand, is that the dictionary omits the superlative form of the fourth compass point, ürjijmus 'southernmost', and the opposite of the word viärrámus, bürijmus 'best', both of which are found in Schlachter. The following superlative spatial indicators, which appear in Schlachter, have also been omitted:

däbbijmus 'closest to here' gaskijmus 'centremost' gäddijmus 'closest to the shore' ulgijmus 'outermost' ustijmus 'farthest'

The degree to which the amount of widespread vocabulary is increased in the new dictionary can also be examined by comparing it with the
Ume Saami material in Lehtiranta's (1989) Yhteissaamelainen sanasto [Common Saami Vocabulary] (YSaS), which is mostly based on Schlachter's dictionary. YSaS contains a total of 161 Proto-Saamic words beginning with $v, 40$ of which do not have an Ume Saami cognate. The new dictionary provides five missing cognates: viärruo 'victim; tax', vuaktijye 'rack for drying nets', vuöhppie 'narrow bay', vuömssie vuöpssie 'span, hand span (unit of measurement)' and vuarruo 'turn; shift'. In addition, the dictionary contains three words in YSaS that were obtained from sources other than Schlachter (vualppuo 'skirt', vuadna 'settlement (in Norway); fjord' and vuarttja vuar(a)tjis 'crow', which is presented in YSaS as vuör'tjee). The new dictionary does, therefore, provide additions, albeit not a great deal. At least the same amount of additional vocabulary would probably be obtained from the archival material that has not been included in the dictionary; Lehtiranta (1989: 8) estimates that more comprehensive source material could increase the amount of common Saami vocabulary known from Ume Saami by one tenth.

All in all, it can be said that the new Ume Saami dictionary will certainly fill its role as a tool for language use. For lexicologists, too, it offers a good number of entries 
that were not previously found in dictionaries, but because of the selection made in the editorial work, it is not suitable for more systematic research on word formation or the structure of vocabulary. Consequently, a scientific dictionary describing all of the recorded Ume Saami vocabulary and its dialectological distribution remains on the researcher's wish list. On the other hand, it would be desirable if dictionary publishers made full use of modern technology: while ordinary language users could benefit from a mobile application or online version of the dictionary, linguistic researchers would also like to see the material made available for research purposes in a structured, digital form that can be used as openly as possible. When it comes to making data openly available, development has been moving in a good direction, and, to give an example from Saami lexicology, Juhani Lehtiranta's planned extensive dialect dictionary of Pite Saami will, according to the author's knowledge, be published as an open database as soon as it is completed.

\section{References}

Arbetsgrupp 2016 = Ubmejesámiengiälan bargguodåhkkie / Arbetsgrupp för umesamiska. 2016-0406. Umesamisk ortografi: Beslut om umesamisk ortografi. Likssjuo: Sámi Giellagáldu.

https://www.sametinget.se/103957 (Accessed 2019-09-22).

Kejonen, Olle. 2019. [Review of] Henrik Barruk, Báhkuogirjjie. Ordbok. Ubmejesámien-dáruon, Dáruonubmejesámien. Umesamisk-svensk, Svensk-umesamisk. Linguistica Uralica LV. 66-69.

Lehtiranta, Juhani. 1989. Yhteissaamelainen sanasto (Mémoires de la Société Finno-Ougrienne 200). Helsinki: Suomalais-Ugrilainen Seura. [3rd edition 2015 available at https://www.sgr.fi/fi/items/show/165] Sámediggi. 2018. Umesamiska. https:// www.sametinget.se/umesamiska (Accessed 2019-09-22).

SChlachter, Wolfgang. 1958. Wörterbuch des Waldlappendialekts von Malå und Texte zur Ethnographie (Lexica Societatis Fenno-Ugricae XIV). Helsinki: Suomalais-Ugrilainen Seura. 